\title{
Funding Infectious Disease Research: A Systematic Analysis of UK Research Investments by Funders 1997- 2010
}

\author{
Joseph R. Fitchett ${ }^{1 *}$, Michael G. Head ${ }^{2}$, Mary K. Cooke ${ }^{2}$, Fatima B. Wurie ${ }^{2}$, Rifat Atun ${ }^{3,4}$
}

1 King's College London, Department of Infectious Diseases, London, United Kingdom, 2 University College London, Department of Infection and Population Health, UCL Royal Free Campus, London, United Kingdom, 3 Imperial College Business School and the Faculty of Medicine, Imperial College London, South Kensington Campus, London, United Kingdom, 4 Harvard School of Public Health, Harvard University, Boston, Massachusetts, United States of America

\begin{abstract}
Background: Research investments are essential to address the burden of disease, however allocation of limited resources is poorly documented. We systematically reviewed the investments awarded by funding organisations to UK institutions and their global partners for infectious disease research.

Methodology/Principal Findings: Public and philanthropic investments for the period 1997 to 2010 were included. We categorised studies by infectious disease, cross-cutting theme, and by research and development value chain, reflecting the type of science. We identified 6165 funded studies, with a total research investment of UK $£ 2.6$ billion. Public organisations provided $£ 1.4$ billion $(54.0 \%)$ of investments compared with $£ 1.1$ billion (42.4\%) by philanthropic organisations. Global health studies represented an investment of $£ 928$ million (35.7\%). The Wellcome Trust was the leading investor with $£ 688$ million (26.5\%), closely followed by the UK Medical Research Council (MRC) with $£ 673$ million (25.9\%). Funding over time was volatile, ranging from $\sim £ 40$ million to $\sim £ 160$ million per year for philanthropic organisations and $\sim £ 30$ million to $\sim £ 230$ million for public funders.
\end{abstract}

Conclusions/Significance: Infectious disease research funding requires global coordination and strategic long-term vision. Our analysis demonstrates the diversity and inconsistent patterns in investment, with volatility in annual funding amounts and limited investment for product development and clinical trials.

Citation: Fitchett JR, Head MG, Cooke MK, Wurie FB, Atun R (2014) Funding Infectious Disease Research: A Systematic Analysis of UK Research Investments by Funders 1997-2010. PLoS ONE 9(8): e105722. doi:10.1371/journal.pone.0105722

Editor: Gemma Elizabeth Derrick, Brunel University, United Kingdom

Received October 18, 2013; Accepted July 28, 2014; Published August 27, 2014

Copyright: (c) 2014 Fitchett et al. This is an open-access article distributed under the terms of the Creative Commons Attribution License, which permits unrestricted use, distribution, and reproduction in any medium, provided the original author and source are credited.

Funding: The authors have no support or funding to report.

Competing Interests: The authors have declared no competing interests exist.

*Email: joseph.fitchett@doctors.org.uk

\section{Introduction}

Since 2000, there has been substantial increase in international financing for global health from donor governments and innovative financing, in particular for infectious diseases.[1]

While the Organization for Economic Cooperation and Development (OECD) tracks donor contributions to overseas development assistance for health, including for selected infectious diseases, there are no internationally adopted systems for tracking innovative financing ${ }^{1}$ or investments in infectious disease research for addressing global health burden, by countries, or by funding entities. To date, few studies have analysed research and development $(\mathrm{R} \& \mathrm{D})$ investments. [2-3]

Annual global research and development $(\mathrm{R} \& \mathrm{D})$ funding for neglected diseases, [4] and funding by the National Institutes of Health (NIH) of the United States (US) Department of Health and Human Services have been estimated for selected years. [5-6] A recent systematic analysis of infectious disease research investments in the United Kingdom (UK) from 1997 to 2010 and burden of disease in 2004 and 2008 revealed mismatches between the amounts of funds invested and the burden of disease caused by the conditions, raising concerns about the efficiency of allocation of the investments in infectious disease R\&D. [2,7]

The World Health Organization (WHO) Consultative Expert Working Group on Research and Development: Financing and Coordination is currently reviewing the feasibility of establishing a global observatory to monitor R\&D investments. [8-11] The initiative was endorsed by member states at the sixty-sixth World Health Assembly this year.

We present the first systematic and comprehensive analysis of investments in infectious disease $\mathrm{R} \& \mathrm{D}$ over the 14 -year period from 1997 to 2010. Specifically, the analysis focuses on investment patterns by global health institutions funding infectious disease research.

\section{Methods}

We obtained data from several sources for infectious disease research studies where funding was awarded between 1997 and 2010 (full list and further resources on methodology are openly available from http://researchinvestments.org/data). Figure 1 shows the sources of data and the numbers of studies explored 


\section{2 studies screened \\ 170452 National Research Register \\ 25113 European Commission \\ 7513 Bill \& Melinda Gates Foundation \\ 14660 Wellcome Trust \\ 1074 Health Technology Assessment \\ 6346 ESRC \\ 30 Healthcare Infection Society \\ 1583 British Heart Foundation \\ 266 Action Medical Research \\ 27 National Institute for Health Research \\ 24 British HIV Association \\ 150 British Lung Foundation \\ 65 British Society for Antimicrobial Chemotherapy \\ 98619 National Institute for Health}

4240 studies provided to authors

2016 Medical Research Council

321 BBRSC

55 Meningitis UK

272 Meningitis Research Foundation

747 Association of Medical Research Charities

52 Department for International Development

547 Cancer Research UK

60 Chief Scientist's Office, Scotland

41 Health Protection Agency

34 Northern Ireland R\&D office

95 directly from researchers

314867 studies excluded

Not infection-related

Veterinary studies

Non-UK host recipient

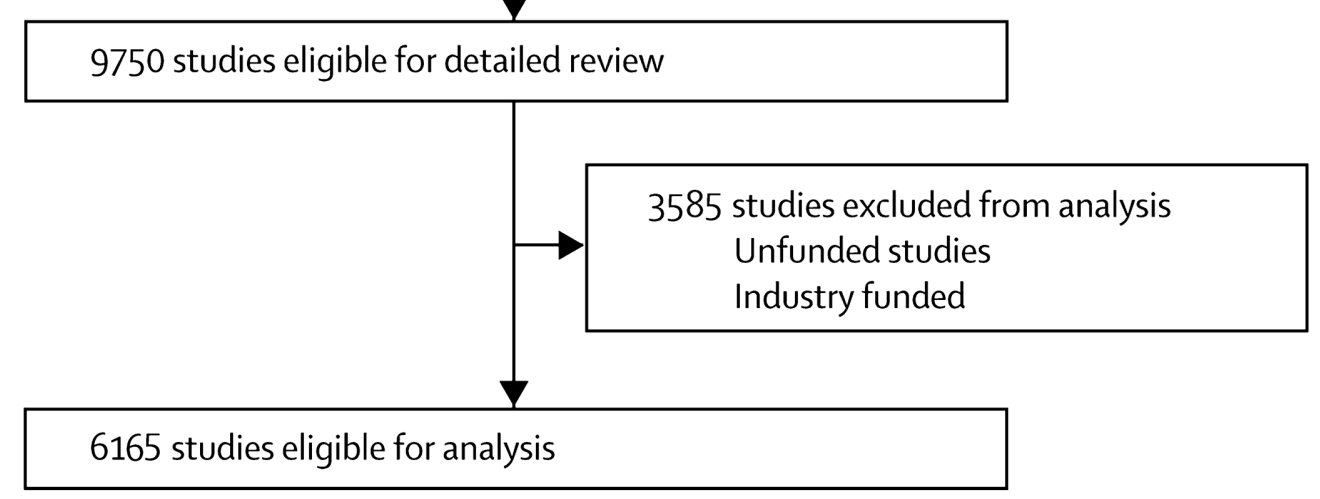

Figure 1. Sources and numbers of studies screened. BBSRC $=$ Biotechnology and Biological Sciences Research Council. ESRC $=E c 0 n o m i c$ and Social Research Council. R\&D = Research and Development. Total number of studies differs by $n=5(0.08 \%)$ from previously published work following ongoing review of the data by the study team [2]. doi:10.1371/journal.pone.0105722.g001

at each stage of screening to reach the final set of studies for detailed analysis. We identified 6165 relevant studies for analysis. We assigned each study to primary disease categories. We outline the methodology for the categorisation of disease areas and classification of the funding sources, elaborated in detail previously.[2]
The overarching dataset was constructed by collating openaccess data and directly contacting the major sources of public and philanthropic funding for infectious disease research studies, including the Wellcome Trust, Medical Research Council and other research councils, UK government departments, the European Commission, Bill and Melinda Gates Foundation, and 


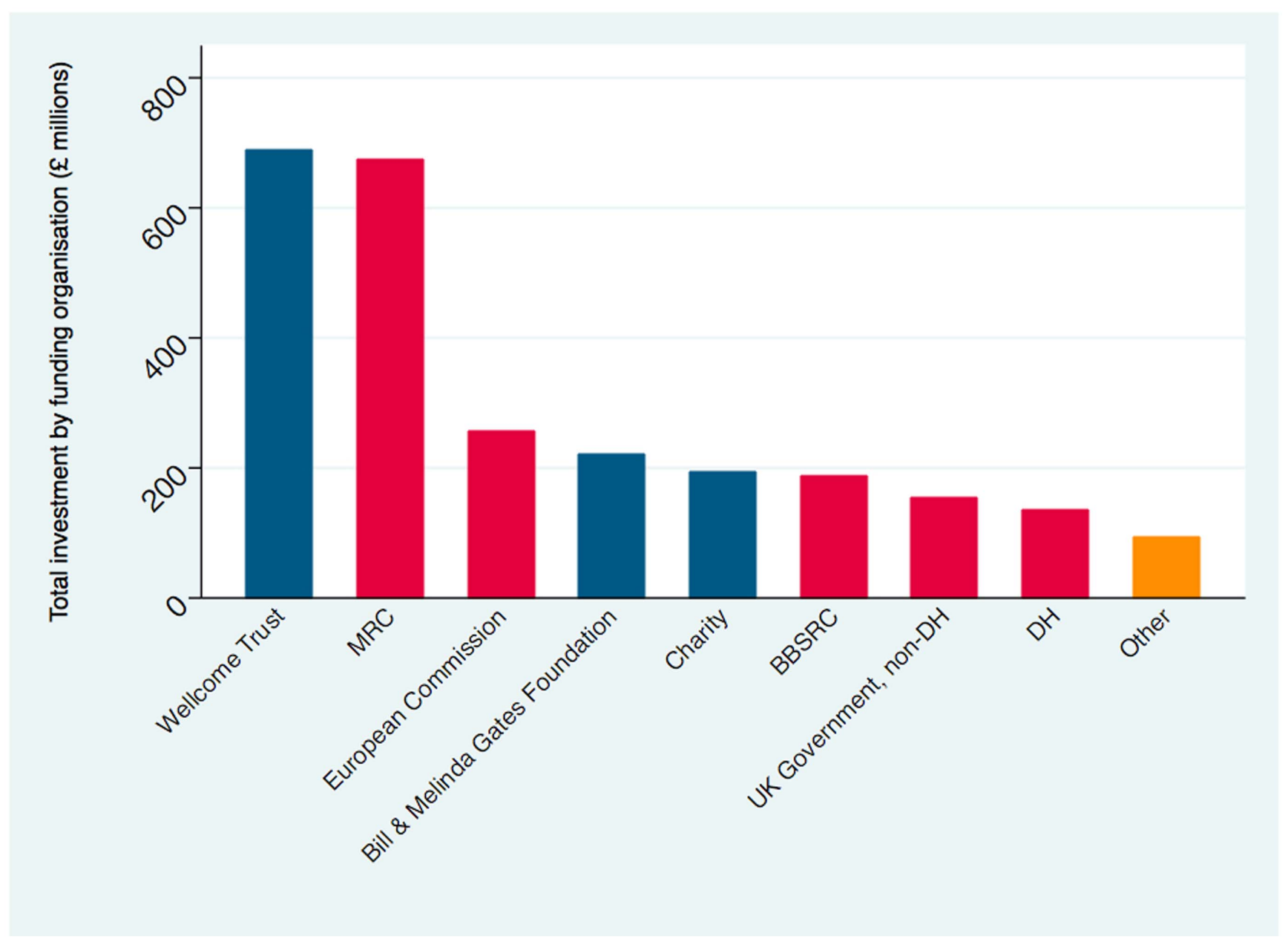

Figure 2. Investment in immunology and vaccine research by funding organisation. BBSRC=Biotechnology and Biological Sciences Research Council. DH = Department of Health. MRC = Medical Research Council. Blue designates philanthropic funding organisations. Red designates public funding organisations. Yellow designates other funding organisations. doi:10.1371/journal.pone.0105722.g002

other research charities. We also searched other databases, including Clinicaltrials.gov and the National Research Register. Within each category, we documented topic-specific subsections, including specific pathogen or disease. We allocated studies to one of four categories along the R\&D continuum: pre-clinical; phases I, II or III; product development; and operational research (which includes epidemiological and implementation research). We developed nine major categories for funding organisations, based on total levels of research investment, and cross-referenced grants from funding organisation to disease categories and stage of $\mathrm{R} \& \mathrm{D}$ funding.

Global health studies include investments to UK institutions with a global partner organisation, or studies predominantly carried out or focused on a country other than the UK. Antimicrobial resistance includes antibacterial, antiviral, antifungal and antiparasitic studies. Reference to sexually transmitted infections excludes HIV/AIDS. Neglected tropical diseases (NTDs) were categorised based on the infections focused on by WHO (for the list of NTDs focused on by WHO see http://www. who.int/neglected_diseases/diseases/en). No private sector funding was included in this analysis as open-access data were limited.

Grants awarded in a currency other than pounds sterling were converted to UK pounds using the mean exchange rate in the year of the award (http://www.oanda.com/currency/average). All grant funding amounts were adjusted for inflation and reported in 2010 UK pounds.

We excluded studies not immediately relevant to infection, veterinary infectious disease research studies (unless there was a zoonotic component) those exploring the use of viral vectors to investigate non-communicable diseases, grants for symposia or meetings, or studies with UK contributions (e.g. as a collaborator), but the funding was awarded to a non-UK institution. Unfunded studies were excluded.

We used Microsoft Excel (versions 2000 and 2007) to categorize studies. Where needed, data were exported into Microsoft Access (versions 2000 and 2007) and specific keyword queries used to select precise sections of the data for analysis. We used Stata (version 11.0; StataCorp LP, Texas) for statistical analysis and to generate figures.

We then systematically analysed the investments by major funding organisations for research projects where a UK institution acted as a leading partner. For multi-centre collaborative studies, we included data where apportioned funding was indicated where UK institutions were the leading partner. For multi-centre collaborative studies where a UK institution was not a leading partner, we were unable to include the funding, which may represent an underestimate (particularly for studies led in the European Union or the United States). We used fold differences to 

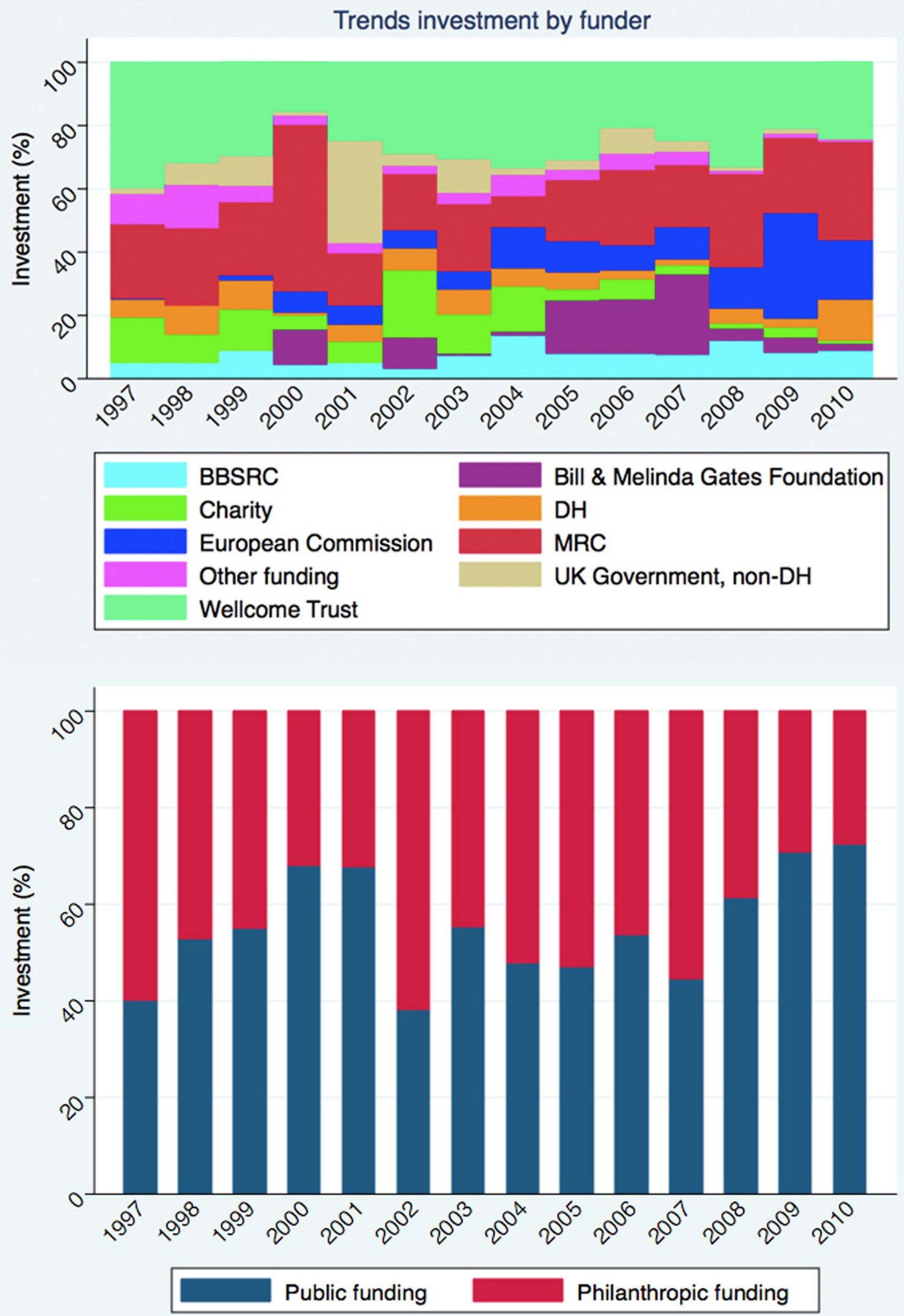
Figure 3. Trends in investment over time: a) stratified by funding organisation, b) stratified by public versus philanthropic funder. BBSRC = Biotechnology and Biological Sciences Research Council. DH = Department of Health. MRC = Medical Research Council. doi:10.1371/journal.pone.0105722.g003

measure the quantity of change in total investment, number of studies, mean grant, and median grant according to disease system, specific infection and funding organisation. We present median grants in the results section to minimize the effect of the skew from few, very large international project awards led by a UK institution.

We used nonparametric Mann-Whitney rank-sum test to assess the distribution of funding by funding source. Nonparametric Ksample test on equality of medians was applied to compare the median funding by funding source, and reported as a chi-squared statistic without Yates' correction for continuity. Nonparametric Wilcoxon signed-rank test was applied when comparing matched data, such as time trends by funding source. The significance for all tests was defined at the $5 \%$ level (two-sided $P=0.05$ ).

\section{Results}

We identified 6165 funded studies in infectious disease research with total research investment of UK £2.6 billion. Of these, 2385 studies $(38.7 \%)$ were investments by public research funding organisations totalling $f 1.4$ billion (54\%), 2874 studies (46.6\%) by philanthropic funding organisations totalling $£ 1$.1 billion $(42.4 \%)$.

Global health studies represented an investment of $\mathcal{L}_{2} 928$ million $(35.7 \%)$. Overall, the mean amount of grant funding awarded was $£ 421733$ (SD £1 315 935) and the median amount of grant funding awarded was $£ 158055$ (IQR £49 $490-£ 352699$ ).

Figure 2 shows the overall ranking of funding organisations by total research investment. The Wellcome Trust was the leading investor in infectious disease research with $£ 688$ million $(26.5 \%)$, closely followed by the UK Medical Research Council (MRC) with $f_{673}$ million (25.9\%). Major funding organisations included the European Commission with f255 million (9.8\%), the Bill and Melinda Gates Foundation with $f_{2} 20$ million (8.5\%) and the Biotechnology and Biological Sciences Research Council (BBSRC) with f186 million (7.2\%). Charities and smaller foundations collectively accounted for $f^{193}$ million of investment $(7.4 \%)$ across 851 studies $(13.8 \%)$.

Figure 3 shows the trends in research funding according to funding organisation over time. The Bill and Melinda Gates Foundation awarded the largest mean and median amount of grant funding at £5 664699 (SD £8 966 093) and £1 488432 (IQR f628 $545-£ 5576$ 863), respectively.

Figure 4 compares the total investment and median amount of grant funding awarded by public and philanthropic investors. The public funding has been larger in 11 of the 14 years studied than philanthropic organisations, which accounts for a significant proportion of the funding ranging from $38 \%$ to $72 \%$ of total annual funding. Funding is volatile ranging, from $\sim £ 40$ million to $\sim £ 160$ million for the philanthropic organisations and $\sim f_{3} 30$ million to $\sim f_{2} 230$ million for the public funders. There is no obvious trend suggesting that the annual funding is increasing and has been fairly flat since 2005. The average median funding awarded by public organisations is larger at $\AA_{2} 255992$ (IQR $\_127$ $167-£ 529610$ ), compared with f146 060 (IQR £52 $433-£ 286$ 518) for philanthropic organisation, almost two fold difference. Figure 5 shows an overall increase in research funding, greatest for public funding organisations. However the levels of funding are volatile over time, and the linear regression best-fit line should be interpreted with caution.

\section{Funding along the research and development stages}

Table 1 shows investment by funding source and research and development $(\mathrm{R} \& \mathrm{D})$ stages. The funding for preclinical research accounted for the majority of investment with $£ 1.6$ billion $(62.4 \%)$ with a median grant of $£ 193149$ (IQR $£ 74157-£ 365587$ ). Public investors funded $57.5 \%$ of the research with philanthropic investors funding $40.5 \%$.

Phase I, II, III clinical trials accounted for $f_{\lrcorner} 147$ million (5.6\%) with the highest median grants at $£ 213471$ (IQR £53 116-£839 713). Public investors funded $73.4 \%$ of the research with philanthropic investors funding $18.7 \%$. Industry funding, a major source of investment in clinical trials, could not be accurately sourced and was excluded from this analysis. Operational research accounted for $\mathcal{f} 697$ million (26.8\%) with the lowest median grants at $f_{28} 232\left(f_{1} 18513-f_{2} 250423\right)$. Philanthropic investors funded $52.7 \%$ of the research with public investors funding $42.0 \%$. Trends in investment over time by $\mathrm{R} \& \mathrm{D}$ pipeline is highlighted in figures $\mathrm{S} 1$ and S2.

Product development research accounted for the least investment with $\mathcal{L}_{133}$ million (5.1\%) with a median grant of $\mathcal{f}_{147621}$ (IQR $£ 38625-£ 409663$ ). Public investors funded $52.0 \%$ of the research with philanthropic investors funding $38.0 \%$.

Table 2 shows the ranking of funding organisation according to research type. The type of science funded by different organisations clearly varies according to the priorities of each funding organisation. The Wellcome Trust, MRC, European Commission, and BBSRC concentrated their investment on preclinical research (70.6\%, 78.4\%, $73.6 \%$ and $100 \%$, respectively). The Bill and Melinda Gates Foundation, Department of Health and other UK government sources concentrated their research investment on operational research $(77.2 \%, 69.2 \%$ and $44.9 \%$, respectively).

\section{Infectious disease system}

Table S1 shows investment by infectious disease system, and specific infection.

The total funding for HIV-related research projects was the greatest with $f^{4} 48$ million $(18.4 \%)$ followed by respiratory infections with $f 419$ million (16.1\%), haematological infections with $f_{4} 413$ million (15.9\%). Gastrointestinal infections received £249 million (9.6\%) and NTDs received £230 million (8.8\%). Public investors accounted for the majority of research funding for HIV, gastrointestinal, hepatic, respiratory, and sexually transmitted infections. In contrast, philanthropic investors accounted for the majority of research funding for NTDs, haematological infections (primarily malaria) and ophthalmic infections. Largest mean grants were awarded to HIV at £625 073 (SD £2 276 762), with grants by public investors 2.46 fold greater than philanthropic investors. Largest median grants were awarded to NTDs at £248 750 (IQR f91 196- $\{451453$ ), with grants by public investors 1.75 fold greater than philanthropic investors.

\section{Specific infection}

Several infections are highly supported by public funding sources compared with philanthropic support. Notable examples include influenza with a 6.38 fold difference $(£ 67.8$ million versus £10.6 million), chlamydia with a 9.02 fold difference ( $£ 17.7$ million versus $f 2.0$ million), campylobacter with a 32.87 fold difference (£22.8 million versus $£ 0.7$ million), and salmonella with a 4.39 fold difference ( 45.0 million versus $£ 10.2$ million). 

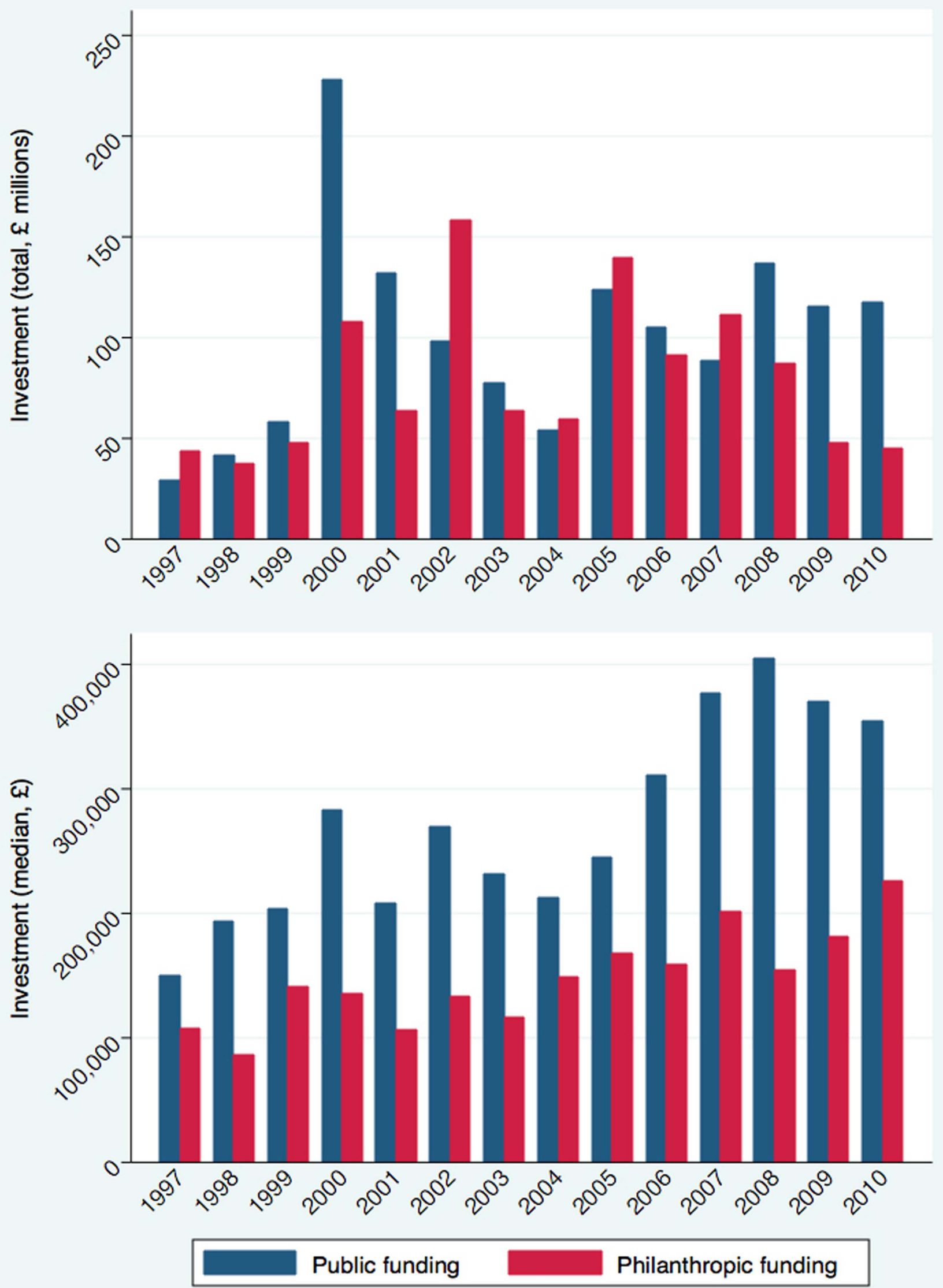
Figure 4. Trends in investment by public versus philanthropic funder over time: a) total research investment, b) median research investment.

doi:10.1371/journal.pone.0105722.g004

Conversely, philanthropic funding sources greatly outweigh public funding for African Trypanosomiasis $(£ 36.0$ million versus $£ 6.7$ million), lymphatic filariasis (£45.2 million versus $£ 1.8$ million), schistosomiasis ( $\_36.3$ million versus $£ 4.4$ million), meningitis (£35.3 million versus $£ 16.3$ million) and $\operatorname{EBV}(£ 32.3$ million versus $f 12.1$ million).

\section{Cross-cutting theme}

Novel technologies to fight infection played an important role in infectious disease research funding. Diagnostics research accounted for $f_{1} 100$ million of investment $(3.9 \%)$, primarily by the Department of Health (23.4\%), Cancer Research UK (17.0\%) and the European Commission (11.5\%). Therapeutics research accounted for $\mathcal{f}^{4} 408$ million $(15.7 \%)$, primarily by the European Commission (22.6\%), Bill and Melinda Gates Foundation (18.4\%) and the Wellcome Trust (16.5\%). Vaccine research accounted for f235 million (9.0\%), with major funders being the MRC (25.6\%), Wellcome Trust (21.4\%) and the European Commission (18.3\%). Trends in investment over time by technologies to tackle infectious diseases are highlighted in figures $\mathrm{S} 1$ and S2. According to type of microbiological organism, viruses were the major area of funding with $\AA_{1} 1.0$ billion $\left(39.5 \%\right.$ ) followed by parasites with $\AA_{\curvearrowleft} 667$ million $(25.7 \%)$, and bacteria with $f_{5} 58$ million (22.6\%). Fungal research attracted $f_{4} 48$ million $(1.9 \%)$ and prion research attracted $f^{2} 34$ million $(1.3 \%)$, primarily from the Department of Health. All microbiological categories were funded primarily by public investors, with exception of parasitology where $67.1 \%$ of funding came from philanthropic investors.

\section{Discussion}

We present the first study to systematically analyse the investment by funding organisations for infectious disease research. Funding trends over time highlight the disparities in funding amounts and stage of funding between funding organisations and the infectious diseases they fund. Studies with a clear global health focus, i.e. those performed outside of the UK, in partnership with an international collaborator, or studying a disease primarily affecting a low-income setting, represented $35.7 \%$ of total investment (£928 million).

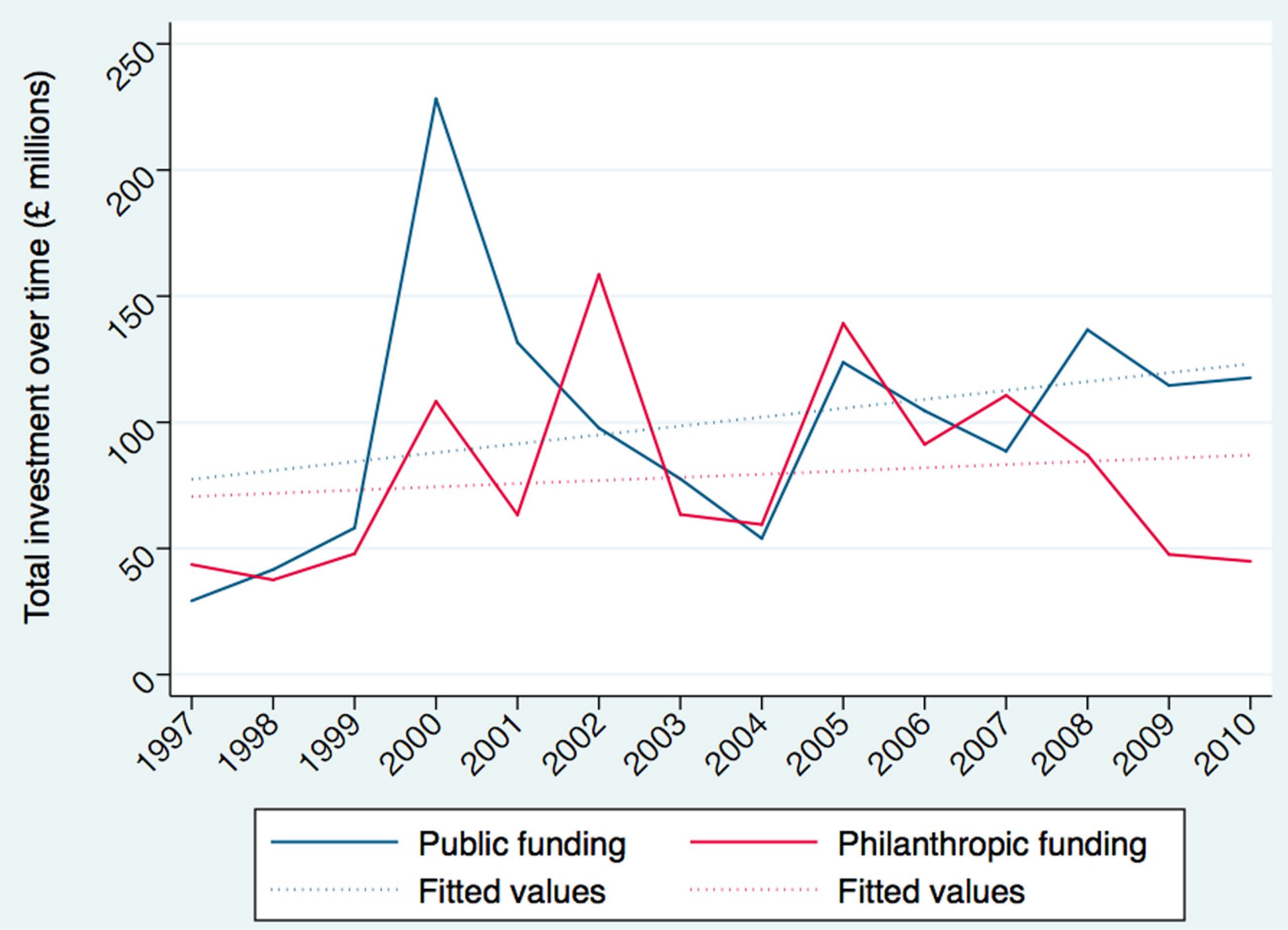

Figure 5. Fitted trend in investment by public versus philanthropic funder over time. Full line represents annual expenditure. Dotted line represents linear regression best-fit line over the 14-year study period. doi:10.1371/journal.pone.0105722.g005 


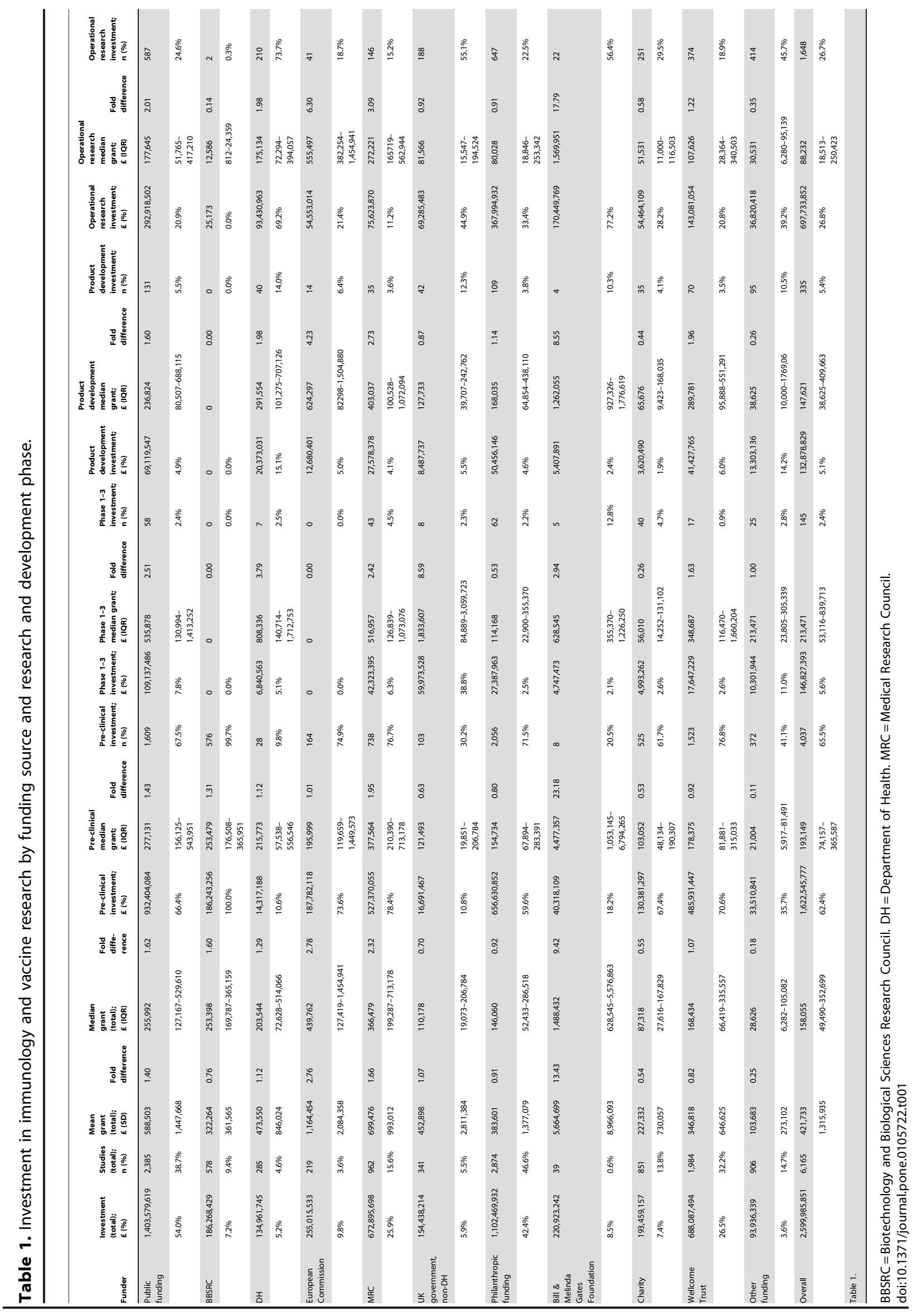


Table 2. Ranking of investment in immunology and vaccine research by a) disease system, b) cross-cutting theme, and c) specific infectious disease.

\begin{tabular}{|c|c|c|c|c|c|}
\hline Disease system & Top funder 1 & Top funder 2 & Top funder 3 & Top funder 4 & Top funder 5 \\
\hline \multirow{2}{*}{$\begin{array}{l}\text { Gastrointestinal } \\
\text { infections }\end{array}$} & BBSRC & Wellcome Trust & MRC & European Commission & UK Government, non-DH \\
\hline & $33.1 \%$ & $31.3 \%$ & $13.4 \%$ & $8.8 \%$ & $4.7 \%$ \\
\hline \multirow[t]{2}{*}{$\begin{array}{l}\text { Haematological } \\
\text { infections }\end{array}$} & Wellcome Trust & $\begin{array}{l}\text { Bill \& Melinda Gates } \\
\text { Foundation }\end{array}$ & MRC & European Commission & Other funding \\
\hline & $34.2 \%$ & $29.9 \%$ & $18.4 \%$ & $6.7 \%$ & $10.9 \%$ \\
\hline \multirow[t]{2}{*}{ Hepatic infections } & MRC & Wellcome Trust & $\mathrm{DH}$ & European Commission & BBSRC \\
\hline & $33.4 \%$ & $19.0 \%$ & $12.5 \%$ & $11.7 \%$ & $4.6 \%$ \\
\hline \multirow[t]{2}{*}{$\begin{array}{l}\text { Neglected tropical } \\
\text { diseases }\end{array}$} & Wellcome Trust & $\begin{array}{l}\text { Bill \& Melinda Gates } \\
\text { Foundation }\end{array}$ & MRC & European Commission & BBSRC \\
\hline & $45.2 \%$ & $29.3 \%$ & $14.8 \%$ & $9.1 \%$ & $3.8 \%$ \\
\hline \multirow[t]{2}{*}{ Neurological infections } & $\mathrm{DH}$ & Wellcome Trust & MRC & $\begin{array}{l}\text { Meningitis Research } \\
\text { Foundation }\end{array}$ & $\begin{array}{l}\text { Bill \& Melinda Gates } \\
\text { Foundation }\end{array}$ \\
\hline & $25.3 \%$ & $24.9 \%$ & $14.9 \%$ & $12.1 \%$ & $3.6 \%$ \\
\hline \multirow[t]{2}{*}{ Ocular infections } & Wellcome Trust & MRC & Charity & UK Government, non-DH & $\mathrm{DH}$ \\
\hline & $63.3 \%$ & $11.9 \%$ & $7.4 \%$ & $6.7 \%$ & $6.4 \%$ \\
\hline \multirow[t]{2}{*}{ Respiratory infections } & Wellcome Trust & MRC & European Commission & BBSRC & $\begin{array}{l}\text { Department for } \\
\text { International Development }\end{array}$ \\
\hline & $32.3 \%$ & $29.6 \%$ & $8.0 \%$ & $6.2 \%$ & $3.3 \%$ \\
\hline \multirow[t]{2}{*}{$\begin{array}{l}\text { Sexually-transmitted } \\
\text { infections }\end{array}$} & MRC & $\mathrm{DH}$ & Cancer Research UK & $\begin{array}{l}\text { Department for } \\
\text { International Development }\end{array}$ & Wellcome Trust \\
\hline & $29.5 \%$ & $19.8 \%$ & $19.1 \%$ & $9.1 \%$ & $6.5 \%$ \\
\hline \multirow[t]{2}{*}{ HIV } & MRC & $\begin{array}{l}\text { Department for } \\
\text { International Development }\end{array}$ & Wellcome Trust & European Commission & $\begin{array}{l}\text { Bill \& Melinda Gates } \\
\text { Foundation }\end{array}$ \\
\hline & $33.8 \%$ & $16.6 \%$ & $15.8 \%$ & $13.5 \%$ & $7.5 \%$ \\
\hline \multirow[t]{2}{*}{ Overall } & Wellcome Trust & MRC & European Commission & $\begin{array}{l}\text { Bill \& Melinda Gates } \\
\text { Foundation }\end{array}$ & BBSRC \\
\hline & $26.47 \%$ & $25.88 \%$ & $9.81 \%$ & $8.50 \%$ & $7.16 \%$ \\
\hline Disease system & Top funder 1 & Top funder 2 & Top funder 3 & Top funder 4 & Top funder 5 \\
\hline \multirow[t]{2}{*}{ Diagnostics } & $\mathrm{DH}$ & Cancer Research UK & European Commission & UK Government, non-DH & Wellcome Trust \\
\hline & $23.4 \%$ & $17.0 \%$ & $11.5 \%$ & $11.2 \%$ & $10.7 \%$ \\
\hline \multirow[t]{2}{*}{ Therapeutics } & European Commission & $\begin{array}{l}\text { Bill \& Melinda Gates } \\
\text { Foundation }\end{array}$ & Wellcome Trust & MRC & $\begin{array}{l}\text { Department for } \\
\text { International Development }\end{array}$ \\
\hline & $22.6 \%$ & $18.5 \%$ & $16.5 \%$ & $16.0 \%$ & $14.1 \%$ \\
\hline \multirow[t]{2}{*}{ Vaccines } & MRC & Wellcome Trust & European Commission & $\begin{array}{l}\text { Bill \& Melinda Gates } \\
\text { Foundation }\end{array}$ & BBSRC \\
\hline & $25.6 \%$ & $21.4 \%$ & $18.3 \%$ & $12.2 \%$ & $6.8 \%$ \\
\hline \multirow[t]{2}{*}{ Bacteriology } & Wellcome Trust & MRC & BBSRC & European Commission & $\mathrm{DH}$ \\
\hline & $29.9 \%$ & $21.8 \%$ & $17.7 \%$ & $8.2 \%$ & $6.3 \%$ \\
\hline \multirow[t]{2}{*}{ Mycology } & BBSRC & Wellcome Trust & MRC & European Commission & National Institute for Health \\
\hline & $30.5 \%$ & $24.7 \%$ & $16.6 \%$ & $13.2 \%$ & $6.2 \%$ \\
\hline \multirow[t]{2}{*}{ Parasitology } & Wellcome Trust & $\begin{array}{l}\text { Bill \& Melinda Gates } \\
\text { Foundation }\end{array}$ & MRC & European Commission & BBSRC \\
\hline & $41.2 \%$ & $25.3 \%$ & $15.2 \%$ & $12.4 \%$ & $2.8 \%$ \\
\hline \multirow[t]{2}{*}{ Prion } & $\mathrm{DH}$ & European Commission & UK Government, non-DH & MRC & Other funding \\
\hline & $65.3 \%$ & $11.3 \%$ & $9.7 \%$ & $6.2 \%$ & $7.6 \%$ \\
\hline \multirow[t]{2}{*}{ Virology } & MRC & Wellcome Trust & Cancer Research UK & European Commission & $\begin{array}{l}\text { Department for } \\
\text { International Development }\end{array}$ \\
\hline & $35.1 \%$ & $18.1 \%$ & $10.5 \%$ & $8.7 \%$ & $6.9 \%$ \\
\hline
\end{tabular}


Table 2. Cont.

\begin{tabular}{|c|c|c|c|c|c|}
\hline Disease system & Top funder 1 & Top funder 2 & Top funder 3 & Top funder 4 & Top funder 5 \\
\hline \multirow[t]{2}{*}{ Overall } & Wellcome Trust & MRC & European Commission & $\begin{array}{l}\text { Bill \& Melinda Gates } \\
\text { Foundation }\end{array}$ & BBSRC \\
\hline & $26.47 \%$ & $25.88 \%$ & $9.81 \%$ & $8.50 \%$ & $7.16 \%$ \\
\hline Specific infection & Top funder 1 & Top funder 2 & Top funder 3 & Top funder 4 & Top funder 5 \\
\hline \multirow[t]{2}{*}{$\begin{array}{l}\text { African } \\
\text { trypanosomiasis }\end{array}$} & Wellcome Trust & MRC & $\begin{array}{l}\text { Bill \& Melinda Gates } \\
\text { Foundation }\end{array}$ & European Commission & WHO \\
\hline & $75.4 \%$ & $15.3 \%$ & $8.8 \%$ & $0.3 \%$ & $0.1 \%$ \\
\hline \multirow[t]{2}{*}{ Aspergillus } & $\begin{array}{l}\text { National Institute } \\
\text { for Health Research }\end{array}$ & Wellcome Trust & Fungal Research Trust & MRC & Other funding \\
\hline & $42.8 \%$ & $35.4 \%$ & $13.4 \%$ & $7.4 \%$ & $1.0 \%$ \\
\hline \multirow[t]{2}{*}{ Campylobacter } & BBSRC & MRC & UK Government, non-DH & Wellcome Trust & Other funding \\
\hline & $82.2 \%$ & $6.5 \%$ & $6.1 \%$ & $2.7 \%$ & $2.5 \%$ \\
\hline \multirow[t]{2}{*}{ Candida } & $\begin{array}{l}\text { National Institute } \\
\text { for Health Research }\end{array}$ & Fungal Research Trust & Dunhill Medical Trust & & \\
\hline & $88.0 \%$ & $9.2 \%$ & $2.7 \%$ & & \\
\hline \multirow[t]{2}{*}{ Chagas disease } & Wellcome Trust & MRC & European Commission & & \\
\hline & $57.3 \%$ & $23.5 \%$ & $19.2 \%$ & & \\
\hline \multirow[t]{2}{*}{ Chlamydia } & Department of Health & UK Government, non-DH & MRC & Wellcome Trust & BUPA Foundation \\
\hline & $49.9 \%$ & $15.9 \%$ & $13.5 \%$ & $7.9 \%$ & $4.0 \%$ \\
\hline \multirow[t]{2}{*}{ Clostridium } & BBSRC & European Commission & Wellcome Trust & MRC & $\begin{array}{l}\text { National Institute for Health } \\
\text { Research }\end{array}$ \\
\hline & $24.3 \%$ & $20.3 \%$ & $19.5 \%$ & $17.1 \%$ & $12.6 \%$ \\
\hline \multirow[t]{2}{*}{ CMV } & MRC & Wellcome Trust & NHS & $\begin{array}{l}\text { Bill \& Melinda Gates } \\
\text { Foundation }\end{array}$ & National Institute for Health \\
\hline & $65.5 \%$ & $24.7 \%$ & $5.6 \%$ & $1.3 \%$ & $0.8 \%$ \\
\hline \multirow[t]{2}{*}{ Dengue } & $\begin{array}{l}\text { Bill \& Melinda Gates } \\
\text { Foundation }\end{array}$ & Wellcome Trust & MRC & European Commission & BBSRC \\
\hline & $76.6 \%$ & $12.5 \%$ & $7.6 \%$ & $2.6 \%$ & $0.8 \%$ \\
\hline \multirow[t]{2}{*}{ Diphtheria } & European Commission & UK Government, non-DH & & & \\
\hline & $84.5 \%$ & $15.5 \%$ & & & \\
\hline \multirow[t]{2}{*}{ E. coli } & BBSRC & Wellcome Trust & MRC & $\begin{array}{l}\text { Economic and Social } \\
\text { Research Council }\end{array}$ & European Commission \\
\hline & $40.9 \%$ & $39.0 \%$ & $5.8 \%$ & $5.1 \%$ & $3.8 \%$ \\
\hline \multirow[t]{2}{*}{ EBV } & Cancer Research UK & MRC & Wellcome Trust & BBSRC & Other funding \\
\hline & $55.9 \%$ & $25.7 \%$ & $14.7 \%$ & $0.9 \%$ & $2.7 \%$ \\
\hline \multirow[t]{2}{*}{ Gonorrhoea } & Wellcome Trust & BBSRC & UK Government, non-DH & NHS & Other funding \\
\hline & $48.9 \%$ & $25.6 \%$ & $15.5 \%$ & $4.4 \%$ & $5.6 \%$ \\
\hline \multirow[t]{2}{*}{ Helicobacter } & MRC & Cancer Research UK & Wellcome Trust & $\mathrm{NHS}$ & Other funding \\
\hline & $33.6 \%$ & $28.8 \%$ & $12.2 \%$ & $5.7 \%$ & $19.8 \%$ \\
\hline \multirow[t]{2}{*}{ Helminths } & Wellcome Trust & $\begin{array}{l}\text { Bill \& Melinda Gates } \\
\text { Foundation }\end{array}$ & MRC & BBSRC & European Commission \\
\hline & $53.7 \%$ & $20.0 \%$ & $14.0 \%$ & $7.3 \%$ & $4.5 \%$ \\
\hline \multirow[t]{2}{*}{ Hepatitis B } & MRC & Wellcome Trust & European Commission & National Blood Service & Department of Health \\
\hline & $43.0 \%$ & $23.3 \%$ & $7.2 \%$ & $4.4 \%$ & $3.6 \%$ \\
\hline \multirow[t]{2}{*}{ Hepatitis C } & MRC & Wellcome Trust & $\mathrm{DH}$ & European Commission & UK Government, non-DH \\
\hline & $35.1 \%$ & $17.1 \%$ & $14.3 \%$ & $12.8 \%$ & $4.5 \%$ \\
\hline \multirow[t]{2}{*}{ HIV } & MRC & $\begin{array}{l}\text { Department for } \\
\text { International Development }\end{array}$ & Wellcome Trust & European Commission & $\begin{array}{l}\text { Bill \& Melinda Gates } \\
\text { Foundation }\end{array}$ \\
\hline & $33.8 \%$ & $16.6 \%$ & $15.8 \%$ & $13.5 \%$ & $7.5 \%$ \\
\hline \multirow[t]{2}{*}{ HPV } & Cancer Research UK & MRC & $\mathrm{DH}$ & European Commission & Wellcome Trust \\
\hline & $50.8 \%$ & $24.4 \%$ & $9.2 \%$ & $4.9 \%$ & $3.4 \%$ \\
\hline HSV & MRC & Wellcome Trust & UK Government, non-DH & BBSRC & Other funding \\
\hline
\end{tabular}


Table 2. Cont.

\begin{tabular}{|c|c|c|c|c|c|}
\hline Specific infection & Top funder 1 & Top funder 2 & Top funder 3 & Top funder 4 & Top funder 5 \\
\hline & $65.8 \%$ & $23.7 \%$ & $5.4 \%$ & $3.2 \%$ & $2.1 \%$ \\
\hline \multirow[t]{2}{*}{ Influenza } & MRC & BBSRC & European Commission & Wellcome Trust & Other funding \\
\hline & $52.9 \%$ & $16.6 \%$ & $12.9 \%$ & $12.7 \%$ & $4.9 \%$ \\
\hline \multirow[t]{2}{*}{ Leishmaniasis } & Wellcome Trust & European Commission & $\mathrm{MRC}$ & BBSRC & \\
\hline & $42.5 \%$ & $35.3 \%$ & $18.2 \%$ & $4.0 \%$ & \\
\hline \multirow[t]{2}{*}{ Leprosy } & Wellcome Trust & & & & \\
\hline & $100.0 \%$ & & & & \\
\hline \multirow[t]{2}{*}{ Listeriosis } & BBSRC & Wellcome Trust & European Commission & MRC & \\
\hline & $40.6 \%$ & $26.2 \%$ & $21.7 \%$ & $11.6 \%$ & \\
\hline \multirow[t]{2}{*}{ Lymphatic filariasis } & $\begin{array}{l}\text { Bill \& Melinda Gates } \\
\text { Foundation }\end{array}$ & MRC & Wellcome Trust & & \\
\hline & $95.5 \%$ & $3.9 \%$ & $0.6 \%$ & & \\
\hline \multirow[t]{2}{*}{ Malaria } & Wellcome Trust & $\begin{array}{l}\text { Bill \& Melinda Gates } \\
\text { Foundation }\end{array}$ & MRC & European Commission & UK Government, non-DH \\
\hline & $34.5 \%$ & $26.1 \%$ & $19.1 \%$ & $13.0 \%$ & $3.9 \%$ \\
\hline \multirow[t]{2}{*}{ Measles } & MRC & European Commission & UK Government, non-DH & $\mathrm{DH}$ & Wellcome Trust \\
\hline & $49.2 \%$ & $35.5 \%$ & $7.3 \%$ & $5.3 \%$ & $2.7 \%$ \\
\hline \multirow[t]{2}{*}{ Meningitis } & Wellcome Trust & $\begin{array}{l}\text { Meningitis Research } \\
\text { Foundation }\end{array}$ & MRC & $\mathrm{DH}$ & Meningitis UK \\
\hline & $27.4 \%$ & $22.3 \%$ & $21.2 \%$ & $7.3 \%$ & $4.4 \%$ \\
\hline \multirow[t]{2}{*}{ Norovirus } & Wellcome Trust & European Commission & MRC & $\mathrm{DH}$ & \\
\hline & $47.7 \%$ & $40.6 \%$ & $9.9 \%$ & $1.8 \%$ & \\
\hline \multirow[t]{2}{*}{ Onchocerciasis } & European Commission & Wellcome Trust & & & \\
\hline & $75.5 \%$ & $24.5 \%$ & & & \\
\hline \multirow[t]{2}{*}{ Pertussis } & Wellcome Trust & UK Government, non-DH & MRC & Other funding & \\
\hline & $46.8 \%$ & $31.0 \%$ & $19.5 \%$ & $2.8 \%$ & \\
\hline \multirow[t]{2}{*}{ Polio } & MRC & UK Government, non-DH & & & \\
\hline & $98.5 \%$ & $1.5 \%$ & & & \\
\hline \multirow[t]{2}{*}{ Pseudomonas } & MRC & BBSRC & Wellcome Trust & $\mathrm{DH}$ & UK Government, non-DH \\
\hline & $33.2 \%$ & $27.6 \%$ & $10.8 \%$ & $7.4 \%$ & $6.9 \%$ \\
\hline \multirow[t]{2}{*}{ Rotavirus } & Wellcome Trust & European Commission & BBSRC & MRC & Other funding \\
\hline & $57.9 \%$ & $20.7 \%$ & $11.2 \%$ & $6.1 \%$ & $4.1 \%$ \\
\hline \multirow[t]{2}{*}{ RSV } & Wellcome Trust & MRC & BBSRC & UK Government, non-DH & Other funding \\
\hline & $44.8 \%$ & $38.5 \%$ & $5.3 \%$ & $5.2 \%$ & $6.3 \%$ \\
\hline \multirow[t]{2}{*}{ Salmonella } & BBSRC & Wellcome Trust & MRC & European Commission & Other funding \\
\hline & $55.0 \%$ & $18.4 \%$ & $17.8 \%$ & $8.1 \%$ & $0.7 \%$ \\
\hline \multirow[t]{2}{*}{ Schistosomiasis } & $\begin{array}{l}\text { Bill \& Melinda Gates } \\
\text { Foundation }\end{array}$ & Wellcome Trust & European Commission & BBSRC & Other funding \\
\hline & $66.2 \%$ & $22.9 \%$ & $8.8 \%$ & $1.3 \%$ & $0.8 \%$ \\
\hline \multirow[t]{2}{*}{ Shigella } & Wellcome Trust & European Commission & MRC & National Institute for Health & \\
\hline & $41.7 \%$ & $25.3 \%$ & $20.0 \%$ & $13.1 \%$ & \\
\hline \multirow[t]{2}{*}{ Syphilis } & Wellcome Trust & MRC & $\mathrm{DH}$ & Terence Higgins Trust & \\
\hline & $53.5 \%$ & $21.7 \%$ & $19.5 \%$ & $5.3 \%$ & \\
\hline \multirow[t]{2}{*}{ Tetanus } & European Commission & Wellcome Trust & & & \\
\hline & $83.6 \%$ & $16.5 \%$ & & & \\
\hline \multirow[t]{2}{*}{ Trachoma } & MRC & & & & \\
\hline & $100.0 \%$ & & & & \\
\hline \multirow[t]{2}{*}{ Tuberculosis } & Wellcome Trust & $\mathrm{MRC}$ & $\begin{array}{l}\text { Department for } \\
\text { International Development }\end{array}$ & European Commission & $\begin{array}{l}\text { Bill \& Melinda Gates } \\
\text { Foundation }\end{array}$ \\
\hline & $40.3 \%$ & $23.2 \%$ & $8.9 \%$ & $7.8 \%$ & $6.3 \%$ \\
\hline VZV & MRC & $\mathrm{DH}$ & Wellcome Trust & Other funding & \\
\hline
\end{tabular}


Table 2. Cont.

\begin{tabular}{llllll}
\hline & & & & & \\
\hline Specific infection & Top funder $\mathbf{1}$ & Top funder $\mathbf{2}$ & Top funder $\mathbf{3}$ & Top funder $\mathbf{4}$ & Top funder $\mathbf{5}$ \\
\hline \multirow{2}{*}{ Overall } & $45.9 \%$ & $22.5 \%$ & $15.5 \%$ & $16.1 \%$ & \\
& Wellcome Trust & MRC & European Commission & $\begin{array}{l}\text { Bill \& Melinda Gates } \\
\text { Foundation }\end{array}$ & BBSRC \\
& $26.47 \%$ & $25.88 \%$ & $9.81 \%$ & $8.50 \%$ & $7.16 \%$ \\
\hline
\end{tabular}

BBSRC $=$ Biotechnology and Biological Sciences Research Council. DH $=$ Department of Health. MRC $=$ Medical Research Council. CMV $=$ Cytomegalovirus. EBV $=$ EpsteinBarr virus. HIV = Human immunodeficiency virus. HPV = Human Papillomavirus. HSV = Herpes Simplex virus. RSV = Respiratory Syncytial virus. VZV = Varicella Zoster virus. doi:10.1371/journal.pone.0105722.t002

Funding trends over time show that charitable funding declines dramatically from 2007, suggesting that the financial crisis adversely impact on health research funding, in particular from smaller charities that were affected by the economic crisis. The volatility of charitable funding is evident, both as a proportion of total investment as well as the sum of total investment. In contrast, funding for infectious disease research was stable, as a proportion of funding and as total investment, for the large funding organisations such as the Wellcome Trust and MRC. The funding landscape also appears to be shifting. These data highlight the dependence on these two leading funders for health research. In addition, the Bill and Melinda Gates Foundation contribute substantially to infectious disease research funding, interjecting a small number of grants of great monetary value. The European Commission emerges as a major funder, particularly from the year 2000 .

Contrasting public and philanthropic funding, total investment is consistently greater from public sources, both in terms of total investment and median investment. Analysing these data over time, the funding from public and philanthropic sources does not appear to be equalising. Fitted values (figure 5) for public and philanthropic funding do show a trend towards increased financing for research overall. However, a drop in philanthropic funding, attributed to the smaller charitable organisations, is clearly apparent from 2007. It will be important to follow up research investments over the coming years to see whether these trends have reverted.

Of note, there is a lack of industry funding from the data. This is primarily due to the methodological decision to exclude industry funding from the analysis, as the open access data available on $\mathrm{R} \& \mathrm{D}$ investments of pharmaceutical firms clearly underestimated the contribution of industry to infectious disease research. Industry partners are likely to contribute more towards clinical trials such as phase 1 , phase 2 , and phase 3 studies. In order to make evidenceinformed decisions, we require complete and accurate data. The pharmaceutical industry should work alongside public and philanthropic funders in order to map, monitor, and evaluate research funding. Publishing such data online in an open access database, such as on www.researchinvestments.org, will be mutually beneficial to both academic institutions and pharmaceutical and biotech companies. In addition, it is unlikely that divulging past and current research investments would jeopardise research in progress. On the contrary, understanding the emerging horizons in current research would allow complementary studies to be performed, and the development of the research base.

We currently lack informative data on the distribution of studies along the research and development pipeline.[10,12] Data from this analysis shows the weight of preclinical research on funding. The great majority of funding is allocated to preclinical work, with a new minority allocated to phase 1,2, 3 trials and product development. Operational research, which includes epidemiological studies, attracted the second greatest level of funding. This is particularly strong in global health studies.[13-14] This trend does not appear to change drastically over time.

We require innovative health financing, and new funding streams to promote innovative delivery of new tools to fight infectious diseases and address the burden of disease.[15-18] Funding allocated for tools to tackle infectious diseases on the other hand is more volatile. There is a clear surge in investment from 2000. This investment wanes slightly over the years until further boosts are made from the year 2005. Most of the investment is allocated to therapeutics or studies involving drugs. Vaccine research receives considerable investment, however this tends to be concentrated according to intermittent funding streams.[19] Diagnostics research appears to be the least well funded of the tools for infectious disease control.

This study maps the research funding landscape for infectious disease research in the UK. The UK is the second greatest funder for global health, after the US.[20-21] It is essential that we understand the funding contributions from other countries, both from the major world economies of the G20 as well as the investments made by local governments and NGOs in low-income settings.[22] An example of a national system that promotes transparency is the extensive online database on the "Research Portfolio Online Reporting Tools" (RePORT) website by the NIH Research, Condition, and Disease Categorization system (http:// report.nih.gov/catego rical_spending.aspx). In addition to a lack of openness with industry funding, there is a lack of openness for large grants awarded to international consortia. In the case of these consortia, although the total grant is often well documented, the international transactions between the lead institution and partner institutions are less well documented.

This work has major implications for academic institutions, governments, funding organisations, and policy makers. Particularly with regards to public funding, there is a duty to invest scarce resources wisely. [23] However, if governments, policy-makers and executives of the funding organisations are allocating resources without accurate knowledge of the current funding terrain, there is bound to be inefficiency.

We urge funding organisations to share data online so that trends in funding may be appropriately assessed. RESIN: Research Investments in Global Health (www.researchinvestments.org) is an initiative that aims to act as an open access portal to facilitate documentation of investments in health research. Inequities in research funding have major implications for global health. Simple measures such as documentation and dissemination of data may act to redress these inequities.

\section{Supporting Information}

Figure S1 Trends in investment over time: a) stratified by research and development phase, b) stratified by infectious disease tool. (JPG) 
Figure S2 Proportion of investment over time: a) stratified by research and development phase, b) stratified by infectious disease tool.

(JPG)

Table S1 Investment in immunology and vaccine research by a) specific infectious disease and b) disease system. CMV = Cytomegalovirus. $\mathrm{EBV}=$ Epstein-Barr virus. $\mathrm{HIV}=$ Human immunodeficiency virus. $\mathrm{HPV}=$ Human Papillomavirus. $\mathrm{HSV}=$ Herpes Simplex virus. RSV = Respiratory Syncytial virus. VZV = Varicella Zoster virus.

(XLS)

\section{References}

1. Atun R, Knaul FM, Akachi Y, Frenk J (2012) Innovative financing for health: what is truly innovative? Lancet 380: 2044-2049

2. Head MG, Fitchett JR, Cooke MK, Wurie FB, Hayward AC, et al (2013) UK investments in global infectious disease research 1997-2010: a case study. Lancet Infect Dis 13: 55-64

3. Fisk NM, Atun R (2009) Systematic analysis of research underfunding in maternal and perinatal health. BJOG 116: 347-356

4. Moran M, Guzman J, Henderson K, Liyanage R, Wu L, et al. (2012) GFINDER - Neglected disease research and development: A five year review. Sydney: Policy Cures. Available: http://www.policycures.org/downloads/ GF2012 Report.pdf. Accessed 12 October 2013

5. Gross CP, Anderson GF, Powe NR (1999) The relation between funding by the National Institutes of Health and the burden of disease. N Engl J Med 340: 1881-1887

6. Gillum LA, Gouveia C, Dorsey ER, Pletcher M, Mathers CD, et al. (2011) NIH disease funding levels and burden of disease. PLoS One 6: e16837

7. Kyratsis Y, Ahmad R (2013) Mapping the terrain of investment in global infectious diseases. Lancet Infect Dis 13:6-7

8. WHO (2012) Research and Development to Meet Health Needs in Developing Countries: Strengthening Global Financing and Coordination. Geneva: World Health Organization. Available: http://www.who.int/phi/CEWG_Report_5_ April_2012.pdf. Accessed 12 October 2013

9. Røttingen J-A, Chamas C (2012) A new deal for global health $R \& D$ ? The recommendations of the Consultative Expert Working Group on Research and Development (CEWG). PLoS Med 9: e1001219

10. Røttingen J-A, Regmi S, Eide M, Young AJ, Viergever RF, et al. (2013) Mapping of available health research and development data: what's there, what's missing, and what role is there for a global observatory? Lancet 382 : $1286-1307$

11. WHO (2012) Draft working paper: A global health R\&D observatory developing a case for its development. Geneva: World Health Organization. Available: http://www.who.int/phi/documents/dwp1_global_health_rd_ observatory_16May13.pdf. Accessed 12 October 2013

\section{Acknowledgments}

We thank the Infectious Disease Research Network for their contribution to this work, and acknowledge the assistance of the research and development funding agencies for provision of data.

\section{Author Contributions}

Conceived and designed the experiments: MGH. Performed the experiments: JRF MGH FBW MKC. Analyzed the data: JRF MGH RA. Wrote the paper: JRF. Approved the final version: JRF MGH FBW MKC RA.

12. Terry RF, Allen L, Gardner CA, Guzman J, Moran M, et al. (2012) Mapping global health research investments, time for new thinking-a Babel Fish for research data. Health Res Policy Syst 10: 28

13. Zachariah R, Ford N, Maher D, Bissell K, Van den Bergh R, et al. (2012) Is operational research delivering the goods? The journey to success in low-income countries. Lancet Infect Dis 12: 415-421

14. Cobelens F, van Kampen S, Ochodo E, Atun R, Lienhardt C (2012) Research on implementation of interventions in tuberculosis control in low- and middleincome countries: a systematic review. PLoS Med; 9: e1001358

15. Stuckler D, King L, Robinson H, McKee M (2008) WHO's budgetary allocations and burden of disease: a comparative analysis. Lancet 372: 15631569

16. Katz I, Komatsu R, Low-Beer D, Atun R (2011) Scaling up towards international targets for AIDS, tuberculosis, and malaria: contribution of global fund-supported programs in 2011-2015. PLoS One 6: e17166

17. Lal SS, Uplekar M, Katz I, Lonnroth K, Komatsu R, et al. (2011) Global Fund financing of public-private mix approaches for delivery of tuberculosis care. Trop Med Int Health 16: 685-692

18. Katz I, Aziz MA, Olszak-Olszewski M, Komatsu R, Low-Beer D, et al. (2010) Factors influencing performance of Global Fund-supported tuberculosis grants. Int J Tuberc Lung Dis 14: 1097-1103

19. Wolfson LJ, Gasse F, Lee-Martin SP, Lydon P, Magan A, et al (2008) Estimating the costs of achieving the WHO-UNICEF Global Immunization Vision and Strategy, 2006-2015. Bull World Health Organ 86: 27-39

20. Dorsey ER, de Roulet J, Thompson JP, Reminick JI, Thai A, et al. (2010) Funding of US biomedical research, 2003-2008. JAMA 303: 137-143

21. Dorsey ER, George BP, Dayoub EJ, Ravina BM (2011) Finances of the publishers of the most highly cited US medical journals. J Med Libr Assoc 99: 255-258

22. McCoy D, Chand S, Sridhar D (2009) Global health funding: how much, where it comes from and where it goes. Health Policy Plan 24: 407-17

23. Head MG, Fitchett JR, Atun R (2013) Global health priorities and research funding - Authors' reply. Lancet Infect Dis 13: 653 